Institute of $\mathbf{F}_{\text {ood and }} \mathbf{A}_{\text {gricultural }} \mathbf{S}_{\text {ciences }}$

\title{
Insect Management for Sweet Corn 1
}

\section{G. S. Nuessly and S. E. Webb²}

Foliar, ear and root feeding insects can routinely cause economic losses to sweet corn if left untreated. The most important pests of sweet corn in Florida are the fall armyworm, corn earworm, lesser cornstalk borer, cutworms, corn silk fly, cucumber beetles, aphids, and wireworms. Less common pests of sweet corn include grasshoppers, corn blotch leafminer, twospotted spider mites, sap beetles, stink bugs, maize weevils and billbugs, white grubs, and white fringed beetles.

\section{Fall Armyworm, Spodoptera frugiperda (J.E. Smith) \\ Description}

Adults (Figure 1) are light brown to ash gray with a $11 / 2$ in. wing span. Several dark and light spots and lines are found on the front wings. The hind wings are lighter with a dark band near the margin. Eggs are deposited in masses of up to 200 eggs, often with more than one layer, and covered with scales from the moth's abdomen. Newly emerged larvae have black heads with all white bodies that become darker and patterned as they grow. Mature larvae grow to about 2 in. and are light green to tan or brown to nearly black. Larvae have six dark bumps (tubercles) on the upper surface of each abdominal segment greater than or equal to the size of their spiracles (small, oval-shaped openings to the trachea on the lateral sides of most segments). The eighth abdominal segment has four distinct dark bumps on the top surface. The top of the first thoracic segment appears as a dark shield, often with three light stripes. Sutures on the front of head form an inverted "Y." Larvae (Figure 2) have three pairs of true legs and five pairs of prolegs. The 3/4 in. long pupae are dark reddish-brown.

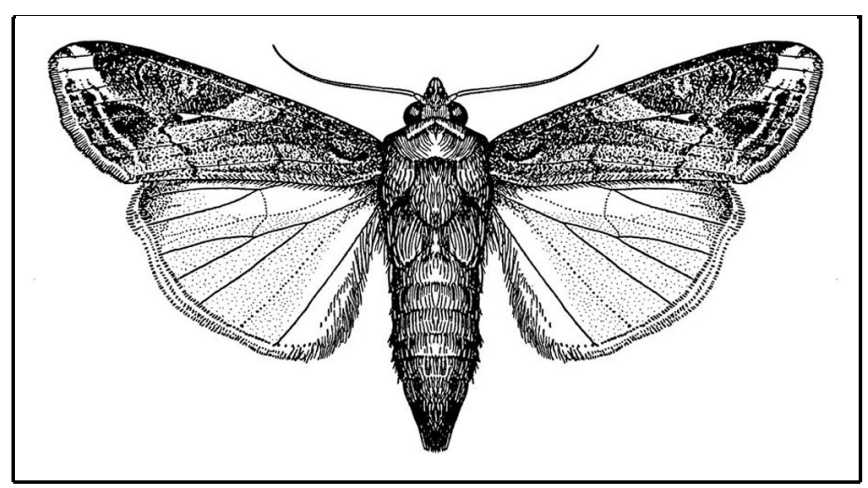

Figure 1. Fall armyworm adult.

1. This document is ENY-472 (which replaces ENY-449), one of a series of the Entomology \& Nematology Department, Florida Cooperative Extension Service, Institute of Food and Agricultural Sciences, University of Florida. Published: November 2001. Revised: July 2003. For more publications related to horticulture/agriculture, please visit the EDIS Website at http://edis.ifas.ufl.edu/.

2. G. S. Nuessly, Associate Professor, Crop Protection, Everglades REC, Belle Glade and S. E. Webb, Associate Professor, Entomology and Nematology Department, Cooperative Extension Service, Institute of Food and Agricultural Sciences, University of Florida, Gainesville, $32611-0640$.

The use of trade names in this publication is solely for the purpose of providing specific information. UF/IFAS does not guarantee or warranty the products named, and references to them in this publication does not signify our approval to the exclusion of other products of suitable composition. All chemicals should be used in accordance with directions on the manufacturer's label. Use pesticides safely. Read and follow directions on the manufacturer's label.

The Institute of Food and Agricultural Sciences is an equal opportunity/affirmative action employer authorized to provide research, educational information and other services only to individuals and institutions that function without regard to race, color, sex, age, handicap, or national origin. For information on obtaining other extension publications, contact your county Cooperative Extension Service office. Florida Cooperative Extension Service/Institute of Food and Agricultural Sciences/University of Florida/Christine Taylor Waddill, Dean. 


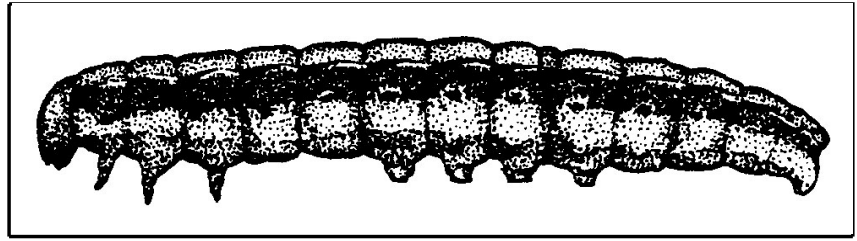

Figure 2. Fall armyworm

\section{Biology}

Adults feed on nectar and other moisture sources. Egg masses are usually deposited under leaves. Larvae emerge from eggs in 3 to 4 days. Prior to tassel push, young larvae feed between leaf veins often on outer portions of leaves before moving into the whorl to feed on young developing leaves. Later in the season young larvae first feed on tassels before moving to the ears or feed directly and complete development on ears. Last (6th) instar larvae leave the plants to pupate in shallow chambers beneath the soil surface. Larvae complete development within 2 to 3 weeks. Adults emerge from the pupal cases in 7 to 10 days to complete a generation in 24 to 35 days.

\section{Damage}

Long thin holes between the leaf veins indicate feeding by first instar larvae. Later instar larvae leave larger holes across veins. Leaves damaged by small to medium sized larvae within the whorl often emerge to display rows of holes. Feeding by mid to late instar larvae frequently results in a shredded appearance to the emerging leaves. Late instar larvae can completely consume the growing point of the plant, and can severely damage the tassel before it emerges from the whorl. Presence of these larvae can be detected by looking into the whorl for a plug of wet excrement (frass plug) blocking the opening. Tassels should be examined for early through mid instar larvae and their damage, including small holes, missing pieces, excrement and tassel pieces on the upper surface of leaves. Fourth through sixth instar larvae pushed from the whorl by the emerging tassel can quickly ruin the ears of at least one of the surrounding plants. All age larvae feed on ears. Young larvae feed on silk and often enter the tip of the ear to feed on silk before damaging kernels, and cob. Examine the silk for damage and presence of small frass. Mid to late instar larvae can enter the ear through the husk, bypassing the silk and causing direct damage to kernels and cob. The husks of ears should be examined for direct entry, particularly in the protected area between the ear and plant stem.

Table 1. Fall armyworms

\begin{tabular}{|c|c|}
\hline $\begin{array}{c}\text { Management } \\
\text { Option }\end{array}$ & Recommendation \\
\hline $\begin{array}{l}\text { Scouting/ } \\
\text { Thresholds }\end{array}$ & $\begin{array}{l}\text { Fields should be monitored at least } \\
\text { weekly until tassel push for young } \\
\text { larvae on leaves and in whorls. } \\
\text { Thresholds used for treatment are } \\
\text { plant age specific, with seedlings } \\
\text { and plants pushing tassel often } \\
\text { treated at } 10 \% \text { or lower infestations. } \\
\text { Plants between these stages are } \\
\text { usually treated when infestations } \\
\text { reach between } 15 \text { and } 20 \% \text {. Fields } \\
\text { should be scouted at least twice } \\
\text { weekly during the ear stage to } \\
\text { detect and control populations before } \\
\text { they cause economic damage. } \\
\text { Treatments during this period are } \\
\text { usually initiated as soon as larvae } \\
\text { are detected. Infestations above a } \\
\text { few percent should elicit more } \\
\text { frequent sampling. Pheromone traps } \\
\text { can be used to monitor relative } \\
\text { presence of the adults in the area. }\end{array}$ \\
\hline
\end{tabular}


Table 1. Fall armyworms

\begin{tabular}{|c|c|}
\hline $\begin{array}{c}\text { Management } \\
\text { Option }\end{array}$ & Recommendation \\
\hline Notes & $\begin{array}{l}\text { It is important to eliminate the larvae } \\
\text { being pushed from the whorl by the } \\
\text { emerging tassel so they do not } \\
\text { damage the sensitive emerging ear } \\
\text { shoots or flag leaves and do not } \\
\text { pupate within the field. Larvae } \\
\text { completing development at tassel } \\
\text { push can emerge as adults to lay } \\
\text { eggs on the crop during the period of } \\
\text { active silk growth. Chemical controls } \\
\text { are most effective against the } \\
\text { younger instars with higher rates and } \\
\text { more frequent applications needed to } \\
\text { try to control later instars. Granular } \\
\text { formulations of several pesticides are } \\
\text { available that reduce the exposure to } \\
\text { non-target organisms by } \\
\text { concentrating the pesticides in the } \\
\text { whorls and leaf axils, particularly } \\
\text { when applied in tight bands over the } \\
\text { rows. Granular formulations are one } \\
\text { of the most effective treatments } \\
\text { available to kill larvae once they have } \\
\text { formed a frass plug within whorls. } \\
\text { The other pesticides are used as } \\
\text { broadcast or banded sprays. Control } \\
\text { of newly emerged larvae on ears is } \\
\text { important to prevent economic } \\
\text { damage. }\end{array}$ \\
\hline $\begin{array}{l}\text { Natural } \\
\text { Enemies }\end{array}$ & $\begin{array}{l}\text { Birds and insect natural enemies } \\
\text { (predators and parasitoids) aid in fall } \\
\text { armyworm control from germination } \\
\text { through tassel push, but generally } \\
\text { do not exert enough pressure to } \\
\text { prevent yield loss in sweet corn. } \\
\text { Birds can cause more damage than } \\
\text { fall armyworms by feeding on } \\
\text { kernels at ear tips within a week of } \\
\text { harvest. }\end{array}$ \\
\hline $\begin{array}{l}\text { Resistant } \\
\text { Varieties }\end{array}$ & $\begin{array}{l}\text { Host plant resistance is emerging as } \\
\text { an effective control strategy against } \\
\text { FAW in sweet corns, including } \\
\text { varieties enhanced with maysin and } \\
\text { Bt genes that allow plants to } \\
\text { produce their own natural control } \\
\text { substances. }\end{array}$ \\
\hline
\end{tabular}

\section{Corn Earworm, Heliocoverpa zea (Boddie)}

\section{Description}

The front wing color is sex dependent. Female fore wings are yellow to pinkish-brown, while those of males are light greenish-brown. Both sexes usually have a dark spot in the middle of the fore wing (Figure 3). Both fore and hind wings have dark margins and the hind wings have a short, narrow band near the middle and two pale spots near the edge of the wing in the dark margin. Both sexes have a wingspan of $11 / 2 \mathrm{in}$. The ball shaped, white to yellow to green eggs have ridges running from top to bottom. Newly emerged larvae are translucent white to yellow with a light brown head. Older larvae vary considerably from dark yellow to green or tan to dark brown. Mature larvae can reach 2 in. Larvae (Figure 4) have three pairs of true legs and five pairs of prolegs. The skin (cuticle) of larvae are covered with microspines (need good hand lens or microscope to see microspines). The dark colored tubercles (larger bumps) on abdominal segments 1, 2 and 8 do not have microspines more than 1/4 the way to their apex. The central area on the inside surface of the mandibles do not have a separate toothed area (observed with microscope after spreading mandibles with pins or forceps). The 3/4 in. long pupae are reddish-brown in color.

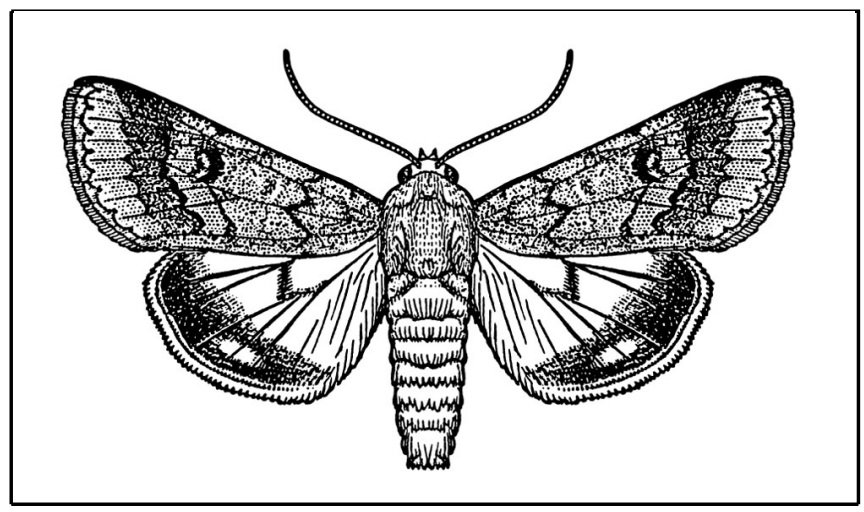

Figure 3. Corn earworm adult.

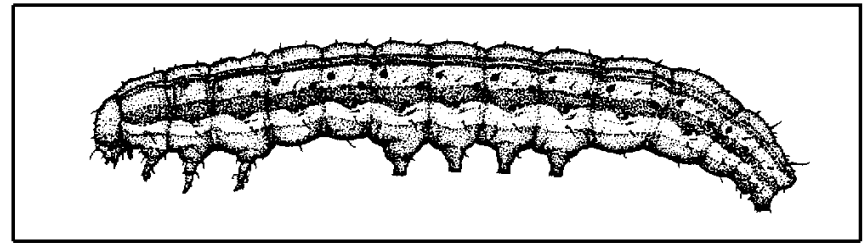

Figure 4. Corn earworm. 


\section{Biology}

Corn earworm moths feed on nectar and other moisture sources. Females deposit their eggs singly or in small groups of less than five on leaves and ears. The eggs are not protected by scales. Larvae emerge from eggs in 3 to 4 days to feed in corn whorls or ears, completing development in 18 to 26 days. Larvae leave plants to pupate within the soil. Adults emerge in 7 to 10 days. Corn earworms complete their development from egg to adult in 28 to 40 days.

\section{Damage}

Young larvae feed between leaf veins often on outer portions of leaves before moving into the whorl to feed on young, developing leaves. Larger larvae can completely consume the growing point of the plant and severely damage the tassel before it emerges from the whorl. More commonly it attacks the ears causing severe damage to silk, kernels and cob. Twenty years ago this was the primary pest of corn throughout Florida. Fall armyworm has largely replaced it as the primary pest, particularly in central and southern Florida, but corn earworm still causes severe damage in corn fields throughout the state. Corn grown in northern Florida counties during the late spring and summer is more likely to have large populations of corn earworm.
Table 2. Corn earworms

\begin{tabular}{|c|c|}
\hline $\begin{array}{c}\text { Management } \\
\text { Options }\end{array}$ & Recommendation \\
\hline $\begin{array}{l}\text { Scouting/ } \\
\text { Thresholds }\end{array}$ & $\begin{array}{l}\text { Fields should be monitored at least } \\
\text { weekly until tassel push for young } \\
\text { larvae on leaves and in whorls. } \\
\text { Thresholds used for treatment are } \\
\text { plant age specific, with seedlings } \\
\text { and plants pushing tassel often } \\
\text { treated at } 10 \% \text { or lower } \\
\text { infestations. Plants between these } \\
\text { stages are usually treated when } \\
\text { infestations reach between } 10 \text { and } \\
20 \% \text {. Fields should be scouted at } \\
\text { least twice weekly during the ear } \\
\text { stage to detect and control } \\
\text { populations before they cause } \\
\text { economic damage. Treatments } \\
\text { during this period are usually } \\
\text { initiated as soon as larvae are } \\
\text { detected. Infestations above a few } \\
\text { percent should elicit more frequent } \\
\text { sampling. Helicoverpa pheromone } \\
\text { traps can be used to monitor } \\
\text { relative presence of the adults in } \\
\text { the area. }\end{array}$ \\
\hline Notes & $\begin{array}{l}\text { It is important to eliminate the } \\
\text { larvae being pushed from the whorl } \\
\text { by the emerging tassel so they do } \\
\text { not damage the sensitive emerging } \\
\text { ear shoots and flag leaves and do } \\
\text { not pupate within the field. } \\
\text { Earworm larvae completing } \\
\text { development at tassel push can } \\
\text { emerge as adults to lay eggs on } \\
\text { the crop during the period of active } \\
\text { silk growth. Insecticides are most } \\
\text { effective against the younger } \\
\text { instars with higher rates and more } \\
\text { frequent applications needed to try } \\
\text { to control later instars. Granular } \\
\text { formulations of several pesticides } \\
\text { are available that reduce the } \\
\text { exposure to non-target organisms } \\
\text { by concentrating the pesticides in } \\
\text { the whorls and leaf axils, } \\
\text { particularly when applied in tight } \\
\text { bands over the rows. The other } \\
\text { pesticides are used as broadcast } \\
\text { or banded sprays. Control of newly } \\
\text { emerged larvae on ears is } \\
\text { important to prevent economic } \\
\text { damage. }\end{array}$ \\
\hline
\end{tabular}


Table 2. Corn earworms

\begin{tabular}{||l|l||}
\hline \hline \multicolumn{1}{|c||}{$\begin{array}{c}\text { Management } \\
\text { Options }\end{array}$} & \multicolumn{1}{c||}{ Recommendation } \\
\hline $\begin{array}{l}\text { Enemies } \\
\text { Enemal }\end{array}$ & $\begin{array}{l}\text { Birds and insect natural enemies } \\
\text { aid in earworm control, but } \\
\text { generally do not exert enough } \\
\text { pressure to prevent yield loss, } \\
\text { particularly in sweet corn. Birds } \\
\text { can cause more damage than corn } \\
\text { earworms by feeding on kernels at } \\
\text { ear tips within a week of harvest. }\end{array}$ \\
\hline Resistant & $\begin{array}{l}\text { Host plant resistance is emerging } \\
\text { as an effective control strategy } \\
\text { against corn earworms in sweet } \\
\text { corns, including varieties enhanced } \\
\text { with Bt genes that allow plants to } \\
\text { produce their own natural control } \\
\text { substances. }\end{array}$ \\
\hline \hline
\end{tabular}

\section{Lesser Cornstalk Borer, Elasmopalpus lignosellus (Zeller)}

\section{Description}

The adults are narrow-winged moths $1 / 2$ to $5 / 8$ in. long (Figure 5). The body and wings of female moths are covered with mostly gray to brown and reddish shiny scales. Males are pale yellow to medium brown with wings bordered with a band of darker scales. Adults fly quickly when disturbed in the field, often landing on the soil several yards away. Males are easily spotted against the darker organic soils. The flat, shingle-like eggs are creamy green and become pink to red at the time of larval emergence. Larvae are patterned with alternating narrow transverse bands of maroon to brown and aqua blue over a cream base. Larvae reach $1 / 2$ to $5 / 8$ in. long at maturity. Larvae have three pairs of true legs and five pairs of prolegs. Larvae are very active when disturbed. Pupae change color from greenish to brown with time and are surrounded by a flimsy silken cocoon.

\section{Biology}

Lesser cornstalk borer moths feed on nectar and other moisture sources. Eggs are deposited singly or in small groups on the soil surface or directly on the stem near the soil surface. Temperature greatly effects development. Larvae emerge in 18 days at $64^{\circ} \mathrm{F}$, but in less than 3 days at $91^{\circ} \mathrm{F}$. They hide

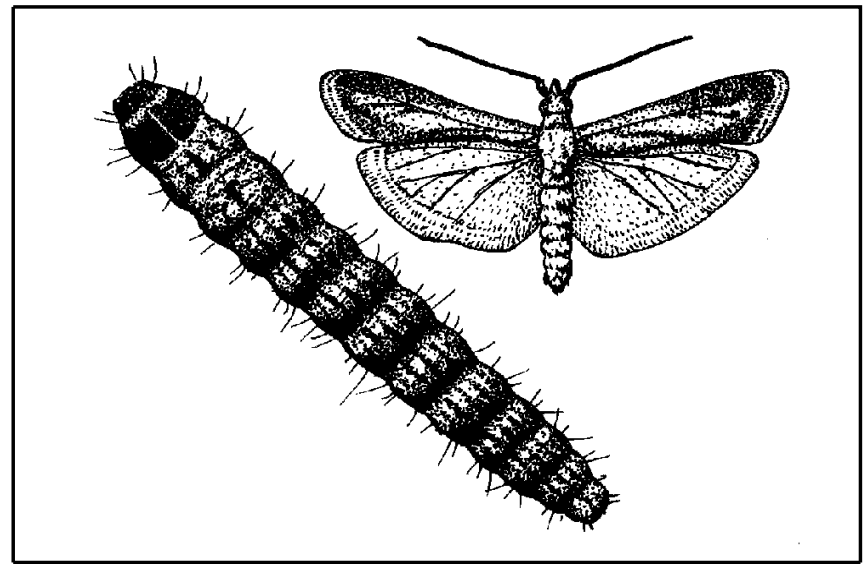

Figure 5. Lesser cornstalk borer.

and feed at base of corn stalks from narrow soil-covered silken tubes $1 / 4$ to $1 / 2$ in. beneath the soil surface. Larvae complete development in 17 to 42 days. The larvae pupate within the soil and adults emerge in 10 to 24 days. Complete generation time is 30 to 84 days.

\section{Damage}

Larvae bore into the corn stem of young plants just below the soil surface and feed up and down the stem. They also bore into larger brace roots of nearly mature plants. Young plants exhibit severe wilting of the youngest two to three leaves. Plants that do not die from this damage often develop several suckers that are bushy and stunted, but they do not produce marketable ears. While wireworms produce similar damage symptoms, corn plants attacked by these beetle larvae are much less likely to survive to produce suckers as when they are attacked by lesser corn borer larvae. Infestations can cause severe stand loss usually in irregular shaped patterns in the field. Damage is usually more severe during dry, warm periods. Larvae may move down a row to kill several seedlings before completing development. 
Table 3. Lesser cornstalk borer

\begin{tabular}{|c|c|}
\hline $\begin{array}{c}\text { Management } \\
\text { Options }\end{array}$ & Recommendation \\
\hline $\begin{array}{l}\text { Scouting/ } \\
\text { Thresholds }\end{array}$ & $\begin{array}{l}\text { Control efforts can be maximized } \\
\text { by estimating the potential for } \\
\text { damage based on adult } \\
\text { monitoring, surrounding crops and } \\
\text { previous field history. Delta wing } \\
\text { pheromone and black light traps } \\
\text { can be used to monitor adults. } \\
\text { Adults are easily visible in fields } \\
\text { as they are quick to fly as one } \\
\text { approaches. Carefully examine } \\
\text { the soil immediately around the } \\
\text { base of the injured plants for } \\
\text { soil-covered silken feeding tubes } \\
\text { loosely attached to the entry hole } \\
\text { at plant base or brace roots. }\end{array}$ \\
\hline Notes & $\begin{array}{l}\text { They tend to be worse in drier } \\
\text { years and on well-drained soils. } \\
\text { However, they can cause severe } \\
\text { damage to sweet corn on heavy } \\
\text { organic soils planted throughout } \\
\text { the year. Larvae may already be } \\
\text { present in the field when seeds } \\
\text { are planted. Wet, cool growing } \\
\text { conditions increase their mortality } \\
\text { and greatly reduce their } \\
\text { developmental rates. In fields with } \\
\text { a high potential for infestation, } \\
\text { at-plant pesticide application } \\
\text { should be considered to reduce } \\
\text { damage. Unfortunately, by the } \\
\text { time field infestations are observed } \\
\text { in corn, damage to the crop has } \\
\text { already occurred. } \\
\text { Post-emergence applications } \\
\text { applied as soon as damage } \\
\text { symptoms appear can limit } \\
\text { additional damage, but may be too } \\
\text { late to prevent economic losses. } \\
\text { Post-emergence applications work } \\
\text { best when banded over the rows } \\
\text { and lightly incorporated into the } \\
\text { soil around the plants. }\end{array}$ \\
\hline $\begin{array}{l}\text { Natural } \\
\text { Enemies }\end{array}$ & $\begin{array}{l}\text { Natural enemies are not thought to } \\
\text { have a significant effect on lesser } \\
\text { cornstalk borers due to their } \\
\text { subterranean habits, silken } \\
\text { feeding tubes and sporadic nature. }\end{array}$ \\
\hline
\end{tabular}

Table 3. Lesser cornstalk borer

\begin{tabular}{|c|c|}
\hline $\begin{array}{l}\text { Management } \\
\text { Options }\end{array}$ & Recommendation \\
\hline $\begin{array}{l}\text { Resistant } \\
\text { Varieties }\end{array}$ & $\begin{array}{l}\text { Host plant resistance is probably } \\
\text { the best strategy for control of this } \\
\text { borer in the future. Resistance } \\
\text { has been noted in lines tested at } \\
\text { CIMMYT in Mexico and domestic } \\
\text { sweet corn varieties enhanced } \\
\text { with a Bt toxin provided overall } \\
\text { control several times greater than } \\
\text { that of insecticides. }\end{array}$ \\
\hline $\begin{array}{l}\text { Cultural } \\
\text { Controls }\end{array}$ & $\begin{array}{l}\text { Field cultivation several weeks in } \\
\text { advance of planting is advised to } \\
\text { allow for decomposition of the } \\
\text { plant residues and completion of } \\
\text { borer development. Planting corn } \\
\text { following corn, sorghum, small } \\
\text { grains, sugar cane, beans, } \\
\text { peanuts, or too quickly behind } \\
\text { recently turned weedy fields can } \\
\text { predispose a crop to damage. } \\
\text { Lesser cornstalk borer does very } \\
\text { well on nutsedge and corn planted } \\
\text { behind sugarcane infested with } \\
\text { these weeds can suffer severe } \\
\text { damage. }\end{array}$ \\
\hline
\end{tabular}

\section{Description}

Cutworm adults are large bodied moths with various dark patterns over light to medium brown or gray base color of fore wings. Shapes and coloration of spots on front wings are diagnostic in the identification of adult cutworm species. The wing spans of both the black (Agrotis ipsilon (Hufnagel)) and variegated (Peridroma saucia (Hubner)) cutworms ranges from $15 / 8$ to $21 / 8$ in, while the wings of the granulate cutworm (Feltia subterranea (F.)) are slightly narrower at $11 / 4$ to $13 / 4$ in. Male and female black cutworm moths (Figure 6) colored differently. However, in both sexes the kidney-shaped (reniform) spot is a dark crescent-shaped ring with a dark line emanating outward and hind wings are whitish to gray with dark scales on veins. The claviform spot (proximal to and beneath reniform spot) is an elongate oval, and the orbicular spot (proximal to reniform spot) is small and round to tear-shaped. Wing color in granulate 
cutworms (Figure 7) varies greatly. Both sexes are recognized by the black bar between the usually pale, basal, round (orbicular) and kidney-shaped (reniform) spots on the fore wings. Hind wings are off-white with veins and margins sometimes darker. There is less distinction between the sexes in wing coloration for variegated cutworms (Figure 8). The kidney-shaped reniform and nearly round orbicular spots (proximal to reniform spot) in the central fore wing are both large and ringed with black. The rear half of the forewings is clay-colored with blackish spots. Hind wings are irridescent to pearly white with brown veins and margins.

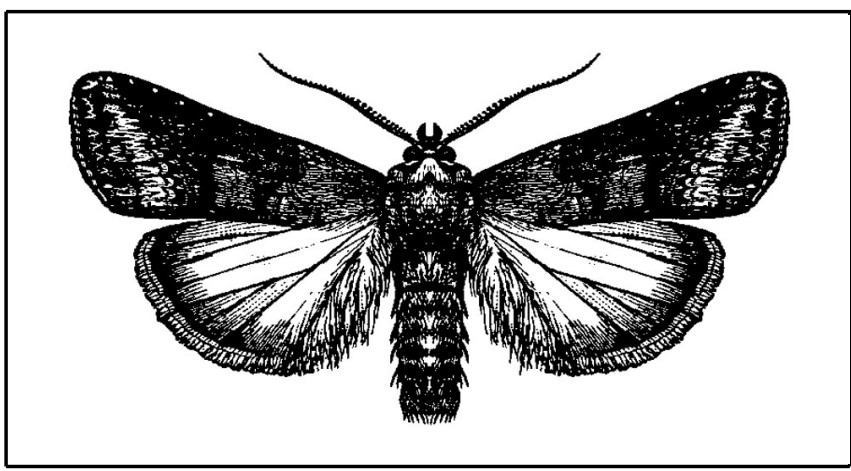

Figure 6. Black cutworm adult.

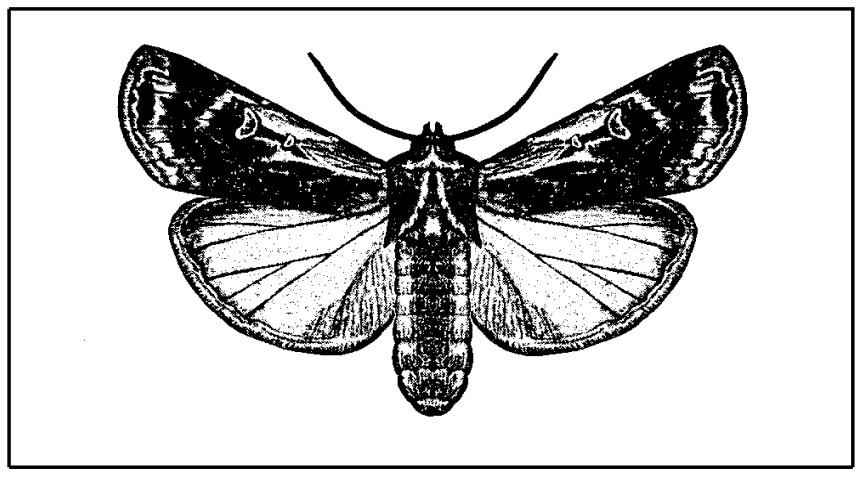

Figure 7. Granulate cutworm adult.

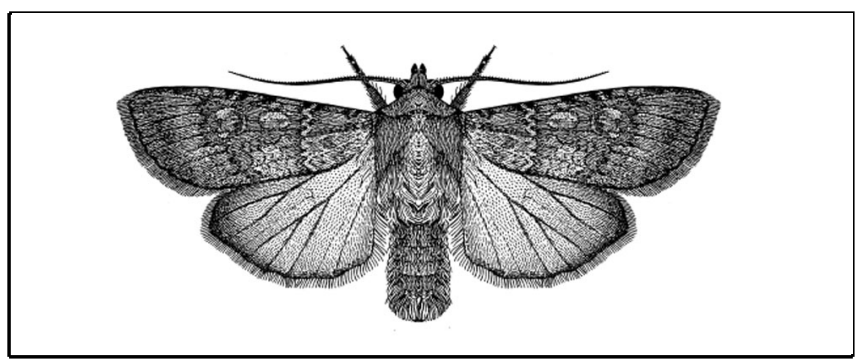

Figure 8. Varigated cutworm moth.

Eggs of all three species are whitish and become variegated brown with age and have ribs radiating downward from the top. Black cutworms eggs are spherical shaped, those of granulate cutworms are rounded with flat bottoms, and variegated cutworms eggs are rounded with rounded bottoms.

All cutworm larvae have sutures on the front of the head that form an inverted "V" and all have three pairs of true legs and five pairs of prolegs. Black cutworm larval color ranges from light gray to black on top and lighter below (Figure 9). Two lighter stripes running down the center of the back are visible on lighter specimens, but all larvae lack an obvious band down their back. Two rows of small, black, raised bumps (tubercles) run down the back; two per segment. Their cuticle is covered with large and small convex, isolated granules (need hand lens or microscope to see granules). Their head is brownish with many dark spots. Granulate cutworm larvae (Figure 10) are gray to reddish brown with dull yellowish subdorsal markings on the abdominal segments. The heads are yellowish to brownish. The undersurface of the body is flecked with white. Granules on their cuticle are isolated, bluntly conical, and project slightly backward. Body color in variegated cutworms (Figure 11) is brownish gray to nearly black on top of back and lighter below. A row of whitish to yellow circular spots run down the center of the back, particularly on the first four abdominal segments. The cuticle is smooth without granulation. An orange to brown line may connect the spiracles, below which there is usually some yellowish to orangish coloration. The head is orange-brown and marked with darker spots. The pupae of all species are reddish brown to brown, 5/8 to $7 / 8 \mathrm{in}$. long and are found in the soil.

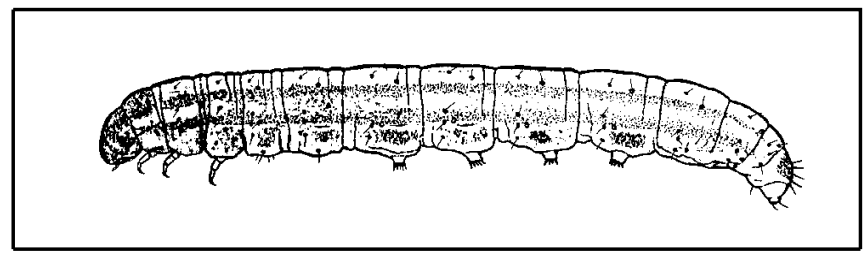

Figure 9. Black cutworm larvae.

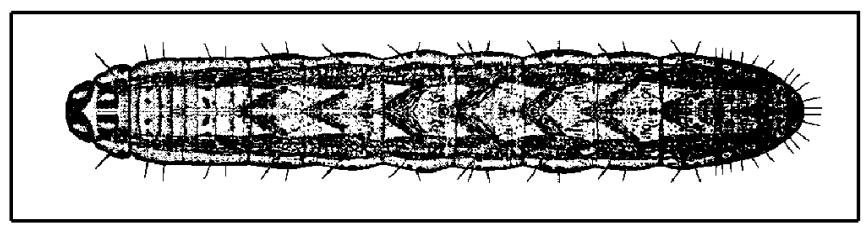

Figure 10. Granulate cutworm larva. 


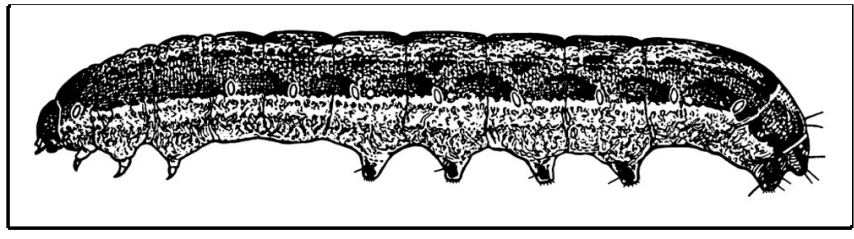

Figure 11. Variegated cutworm larva.

\section{Biology}

Cutworm moths feed on nectar and other moisture sources. Moths begin depositing eggs on field debris, stubble or leaves near the soil surface 7 to 10 days after emergence. Black cutworm eggs are deposited singly or in groups of up to 30 , granulate cutworms eggs are deposited singly or in small groups and variegated cutworms deposit masses of up to several hundred eggs. Larvae emerge from eggs in 3 to 6 days. Larvae tend to curl up into a ring when disturbed or handled. They may also bite and release a greenish-brown fluid. They feed on leaves and stems of mostly young plants. Older larvae (4th instar and later) can reach 2 in. in length and can cut plants off at their bases and drag them to their burrow in soil. Larvae complete development in 20 to 40 days. Larvae pupate within a chamber in the soil. Adults emerge in 10 to 20 days. Generation time for cutworms is 43 to 76 days, depending on temperature.

\section{Damage}

These cutworms are pests of corn and most other vegetables throughout Florida. Damage includes leaf feeding and stand loss due to cutting off entire plants. Black cutworms do most of their feeding at ground level. Larvae feed on young plants, cutting off leaves, or in later instars, entire plants. Populations of this pest tend to be higher in weedy and in wet fields. Granulate cutworm larvae can cut off entire seedling plants, as well as climb and feed on leaves of older plants. This cutworm is not associated with weedy fields as is the black cutworm. First instar larvae stay on plants, while older larvae climb and feed on plants only during night. Variegated cutworm larvae cut off seedlings at ground level or defoliate older plants.
Table 4. Cutworms

\begin{tabular}{|c|c|}
\hline $\begin{array}{c}\text { Management } \\
\text { Options }\end{array}$ & Recommendation \\
\hline $\begin{array}{l}\text { Scouting/ } \\
\text { Thresholds }\end{array}$ & $\begin{array}{l}\text { Seedling corn should be scouted } \\
\text { as frequently as twice per week to } \\
\text { detect cutworms or their damage, } \\
\text { particularly in areas known for this } \\
\text { pest. Young larvae may be found } \\
\text { grouped together on foliage, but } \\
\text { older larvae will usually be found } \\
\text { singly in soil or beneath leaf trash } \\
\text { during the day. Adults can be } \\
\text { monitored with black light and pherom }\end{array}$ \\
\hline Notes & $\begin{array}{l}\text { Larvae may already be present in } \\
\text { the field when seeds are planted. } \\
\text { Pesticides are available for } \\
\text { at-plant, pre- and post-emergence } \\
\text { broadcast and banded } \\
\text { applications. Post emergence } \\
\text { applications are the most efficient. }\end{array}$ \\
\hline $\begin{array}{l}\text { Natural } \\
\text { Enemies }\end{array}$ & $\begin{array}{l}\text { Natural enemies such as parasitic } \\
\text { wasps, flies and predacious ground } \\
\text { beetles can exert tremendous } \\
\text { control pressure that may } \\
\text { approach } 80 \% \text {. Larvae are also } \\
\text { targets for attack by pathogenic } \\
\text { fungi and viruses. However, } \\
\text { seedlings emerging in fields } \\
\text { without resident natural enemy } \\
\text { populations can experience } \\
\text { significant stand loss from first } \\
\text { generation cutworms. }\end{array}$ \\
\hline $\begin{array}{l}\text { Cultural } \\
\text { Controls }\end{array}$ & $\begin{array}{l}\text { Weedy fields quickly rotated to } \\
\text { corn have higher potential for stand } \\
\text { loss due to older larvae cutting off } \\
\text { the emerging plants. }\end{array}$ \\
\hline
\end{tabular}

\section{Corn Silk Fly, Euxesta stigmatias Loew}

\section{Description}

These $3 / 8$ to $5 / 16$ in. long flies (Figure 12 ) have a dark green body with a slight metallic sheen, normal length black legs (not long like the predacious long-legged flies), and red to brown eyes. Their wings are patterned with four dark horizontal bands. The end of the male's abdomen is rounded while that of the female is terminated by a trapezoidal segment from which a long ovipositor is extended during egg deposition. Thin, 1/16 in. long white eggs are 
deposited in silk channels, between ends of husks and around armyworm and earworm entrance and exit holes in husk of corn ears. The larvae (Figure 13) are white to pale yellow, narrow, legless maggots, reaching 3/8 to 7/16 in. long, with black mouth hooks. Maggots do not molt out of their last cuticle, but complete metamorphosis within it. The resulting delicate puparium is light to medium brown.

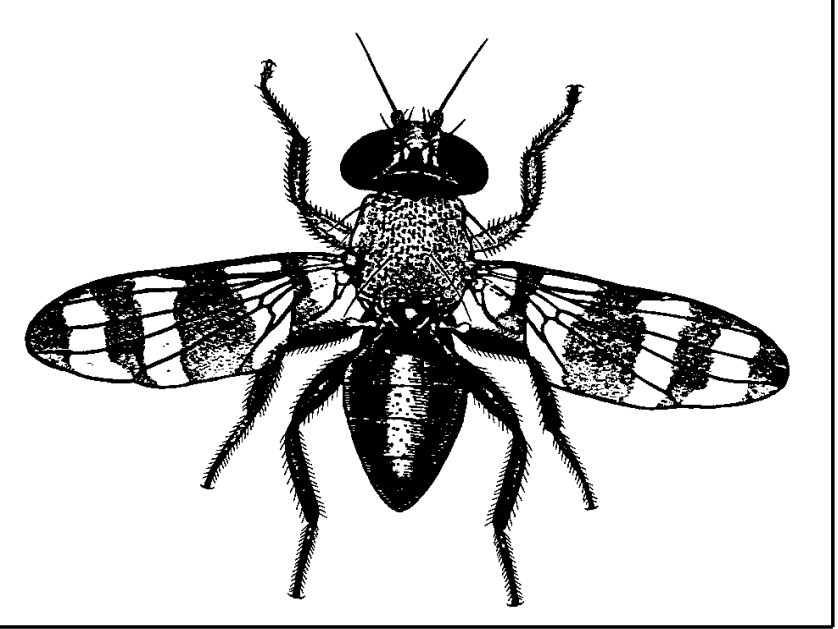

Figure 12. Corn silk fly adult. Credits: J. F. Butler

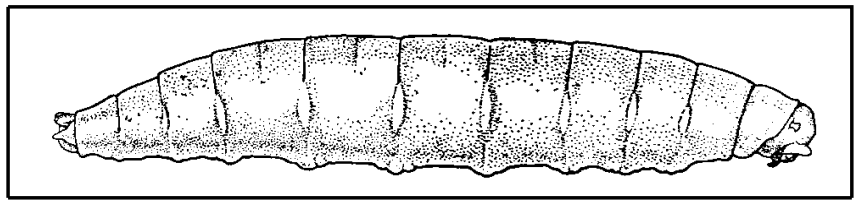

Figure 13. Corn silk fly larva.

\section{Biology}

This insect is saprophytic and feeds and reproduces on a wide variety of over-ripe and rotting fruits, vegetables, and sugarcane. Adults lap up fluids and pollen with their extendable mouth parts.

Females will deposit eggs into sweet corn ears for at least 3 weeks after silk initiation, but seem to prefer ears with fresh silk. Adults are active runners on plants often performing elaborate behaviors involving wing flapping and running at and around other corn silk flies. Mated females are most often observed on ears below the overhanging silks. Larvae emerge from eggs in 2 to 4 days and start feeding on silks just inside the silk channel. Many larvae complete development on silks without causing any direct injury to kernels. But those that continue into the ear feed extensively on kernels at the tips of the ear, or may disperse randomly throughout the ear to feed on kernels. Larvae complete development in 15 to 21 days. Exposed larvae quickly seek shelter by crawling or flicking themselves from the ears by grabbing and quickly releasing the end of their abdomen with their mouthhooks. The great majority of larvae leave the ears to pupate within the soil, but a few pupate in the silk near the opening to the silk channel. Adults emerge from their puparia in 7 to 8 days to complete a generation in 25 to 32 days.

\section{Damage}

The geographic range of this insect has spread up the Florida peninsula during the last decade from the Homestead region. This fly is a year round pest of corn in southernmost Florida. Corn grown just south of Lake Okeechobee is attacked primarily in the late winter and spring. Corn in central Florida is attacked in late spring and early summer. North Florida corn is prone to attack during the summer. This pest damages ears in several ways. By damaging silks, the larvae disrupt pollination and reduce kernel density. Larval feeding on silks and at ear tips that doesn't result in kernel damage can still result in throwing the ears out of grade. Damaged silks in this moist environment turn golden to medium brown and soon begin to ferment. This can lead to secondary infestations of sap (picnic) beetles that are drawn to the released volatiles from the rotting silks. However, near-mature larvae are just as likely to damage individual kernels distributed throughout ears rendering them completely unmarketable. In south Florida, and other areas with appropriate local food reservoirs, these flies are quick to reenter treated fields. Therefore, damage along field margins and across fields with large field edge to acreage ratios can be substantial.

Table 5. Corn silkfly

\begin{tabular}{||l|l||}
\hline $\begin{array}{c}\text { Management } \\
\text { Options }\end{array}$ & \multicolumn{1}{c||}{ Recommendation } \\
\hline Thresholds & $\begin{array}{l}\text { Adults are usually found on the } \\
\text { tassels and upper leaves early in the } \\
\text { morning and late in the afternoon. } \\
\text { This is the best time to scout and to } \\
\text { control them with chemical } \\
\text { insecticides. They move down the } \\
\text { plants, or at least into shaded parts of } \\
\text { the plants, during the day. }\end{array}$ \\
\hline \hline
\end{tabular}


Table 5. Corn silkfly

\begin{tabular}{||l|l||}
\hline \hline $\begin{array}{l}\text { Management } \\
\text { Options }\end{array}$ & \multicolumn{1}{c|}{ Recommendation } \\
\hline Notes & $\begin{array}{l}\text { Organophosphate materials have the } \\
\text { quickest activity and best residue } \\
\text { against this pest. Pyrethroids work } \\
\text { well on contact, but their residues } \\
\text { may only cause temporary knock } \\
\text { down, followed by recovery of adults. }\end{array}$ \\
\hline $\begin{array}{l}\text { Natural } \\
\text { Enemies }\end{array}$ & $\begin{array}{l}\text { Web and non-web spinning spiders } \\
\text { feed on adults. Fire ants, predacious } \\
\text { ground beetles, earwigs and spiders } \\
\text { feed on larvae on the soil surface. }\end{array}$ \\
\hline Resistant & $\begin{array}{l}\text { While cultivars with high maysin } \\
\text { content impart partial resistance to } \\
\text { this insect, no commercial varieties } \\
\text { are currently available with this } \\
\text { compound. }\end{array}$ \\
\hline Cultural & $\begin{array}{l}\text { Avoid planting to fields surrounded by } \\
\text { other host crops, such as tomato or } \\
\text { peppers, particularly if it is possible } \\
\text { that these crops will be abandoned } \\
\text { during the silking to harvest period of } \\
\text { sweet corn. }\end{array}$ \\
\hline \hline
\end{tabular}

\section{Cucumber Beetles}

\section{Description}

Adult banded cucumber beetles (Diabrotica balteata LeConte) (Figure 14) are small (1/4 to 3/8 in. long) and oval-shaped with a dirty yellow to dark green thorax and abdomen. The yellow transverse bands across the wing covers (elytra) and red to reddish-brown heads serve to separate them from the southern or spotted root worm adults (Diabrotica undecimpunctata howardi Barber) which have 12 black spots arranged in 3 rows across their elytra. The third tarsal segment on all legs in both species is laterally swollen into two lobes with the last (fourth) tarsal segment originating from between the lobes. Both species produce small, oval-shaped, pale yellow eggs. The white, elongate and soft bodied larvae have three pairs of minute legs. Larvae are indistinguishable between the two species. The white to pale green pupae are found within loosely woven cocoons in the soil.

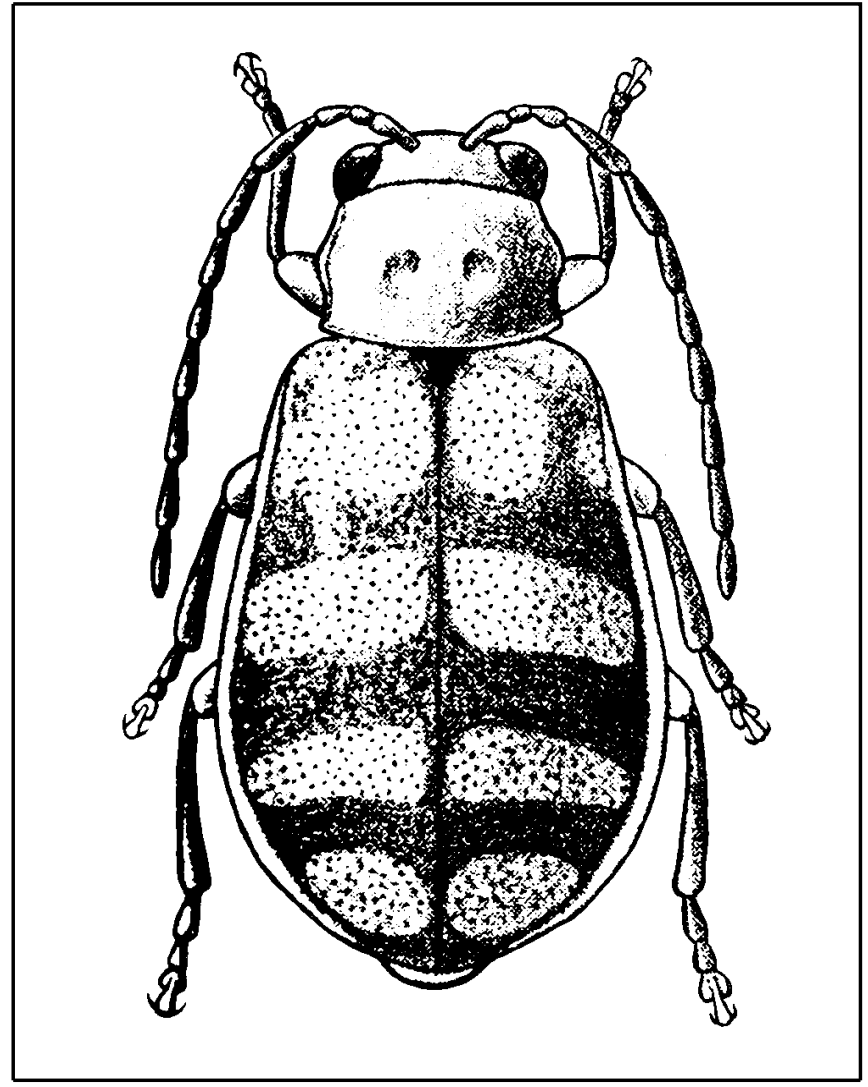

Figure 14. Banded cucumber beetle.

\section{Biology}

Adults feed on young corn leaves, anthers and silk. Adults enter the soil to deposit eggs in clusters of up to 12 near roots. Larvae emerge in 6 to 8 days and feed on roots and other soft tissue at the base of the stalks. Larvae complete development in 15 to 22 days feeding on corn roots. Adults emerge in 16 to 20 days. Banded cucumber beetles complete development in 35 to 50 days.

\section{Damage}

Cucumber beetles are found throughout Florida, with the banded species more common in central and south Florida and the spotted one more common in northern Florida. Larvae damage roots and can enter the corn stalk just above the roots where they can eat the crown and kill the buds of young plants. Bacterial wilt and other pathogens can enter the plant through these wounds. Severe root damage can result in lodging. However, estimates of yield effects for larval or adult feeding have not been determined for Florida corn. Adults are common throughout the winter months in south Florida. While preferring to feed on 
weeds in the genus Amaranthus (pig weeds), adults can cause serious foliar damage to corn and other vegetables. Adult feeding produces irregular shaped, often elongate holes in young leaf tissue within the whorls. Delayed growth, plant stunting, and stand loss can result from heavy feeding damage to whorls of seedlings. Feeding damage to older leaves is evidenced by notched leaves, window paning, and irregular patches with only the veins remaining. Silk pruning by adults can result in blanks within the ears. Adults are good fliers and can invade and damage fields quickly.

Table 6. Cucumber beetles

\begin{tabular}{|c|c|}
\hline $\begin{array}{c}\text { Management } \\
\text { Options }\end{array}$ & Recommendation \\
\hline $\begin{array}{l}\text { Scouting/ } \\
\text { Thresholds }\end{array}$ & $\begin{array}{l}\text { Seedling and silking stage plants } \\
\text { are most sensitive to adult feeding. } \\
\text { Look for adults, feeding damage } \\
\text { and thread-like or oily spots of fecal } \\
\text { material at feeding sites while } \\
\text { scouting for army- and ear-worms. }\end{array}$ \\
\hline Notes & $\begin{array}{l}\text { Chemical control of adults is } \\
\text { through contact or bait insecticides. } \\
\text { This latter type selectively treats } \\
\text { the beetles as they eat the baits. } \\
\text { Numerous pesticides are labeled for } \\
\text { mostly at-plant treatment of } \\
\text { cucumber beetle larvae. }\end{array}$ \\
\hline $\begin{array}{l}\text { Natural } \\
\text { Enemies }\end{array}$ & $\begin{array}{l}\text { Several predacious insects and } \\
\text { spiders prey on these insects, but } \\
\text { migration of large numbers can } \\
\text { quickly overwhelm the natural } \\
\text { enemy complex. }\end{array}$ \\
\hline $\begin{array}{l}\text { Cultural } \\
\text { Controls }\end{array}$ & $\begin{array}{l}\text { Control of cucumber beetle infested } \\
\text { weeds on ditch banks and } \\
\text { surrounding fields should be timed } \\
\text { so that beetles are not forced to } \\
\text { look for food during sensitive } \\
\text { periods in sweet corn development. }\end{array}$ \\
\hline
\end{tabular}

\section{Wireworms or Click Beetles}

\section{Description}

The adult stage (Figure 15) of this insect is a slender, somewhat flattened, medium to dark brown or gray beetle between $1 / 2$ and $7 / 8 \mathrm{in}$. long. The exoskeleton is smooth or with very short hairs. They have a large tooth-like projection between the rear legs that fits into a groove on the undersurface of the abdomen. These beetles feign death when disturbed and can then right themselves from their backs by quick flexion at the juncture of the thorax and abdomen. This behavior produces a clicking sound in some species of click beetles. The larvae are called wireworms (Figure 16) and have narrow, hardened, creamy yellow to orangish-brown, tubular bodies. Characteristic hardened projections on the next to last abdominal segment can be used to identify them to species. They have three pairs of short true legs and no prolegs and can reach 1 1/4 in. long. Pupae are not formed within a cocoon and their legs, antennae and wing buds are completely visible.

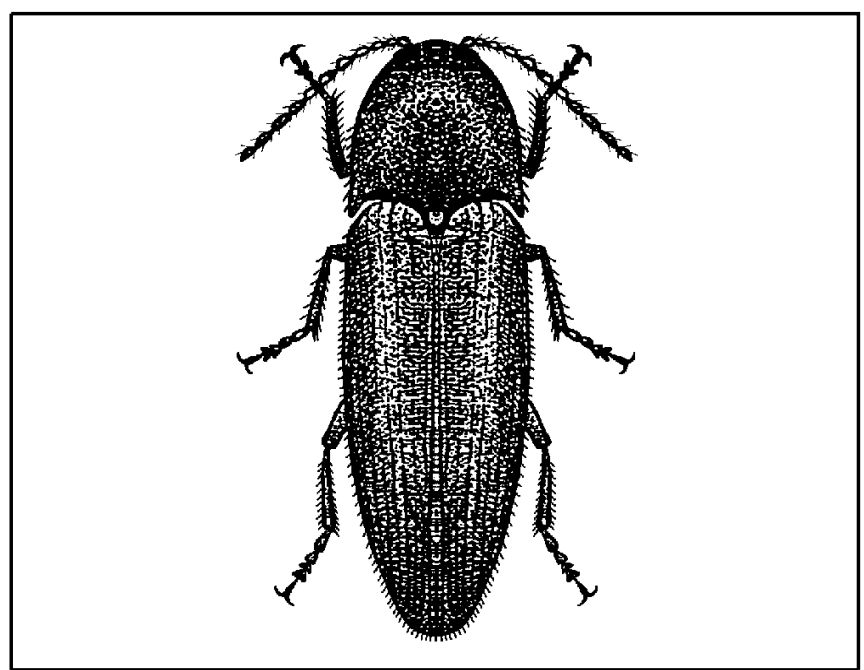

Figure 15. Adult stage - Click beetle.

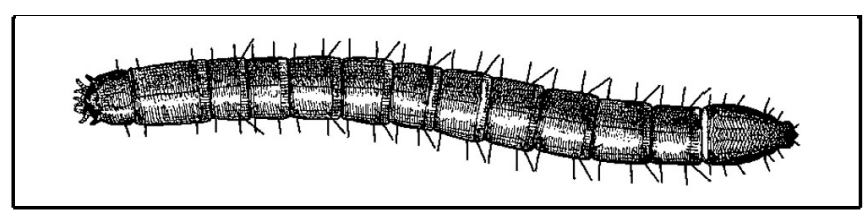

Figure 16. Corn wireworm larva.

\section{Biology}

Adults feed on living and decaying plant material and are frequently observed in corn leaf axils and whorls during the late spring. Eggs are deposited in soil near plant roots, particularly around grasses, during summer months. Wireworms take two to several years to complete larval development. The pupal stage is passed in the soil from which adults emerge within 2 weeks. 


\section{Damage}

Larvae attack seeds, roots, and crowns of plants below the soil surface. They chew into the base of plants and then hollow out the stem, eliminating the growing points of young plants. Young plants first exhibit severe wilting and desiccation of the youngest leaves. Such damage to young plants results in stand loss. Wireworm damage symptoms are nearly identical to those of lesser cornstalk borer, although young plants damaged by the latter are much more likely to send up suckers than those damaged by wireworms. Wireworms also do not form silken feeding tubes as do lesser cornstalk borer larvae. Lodging results following strong winds and rains when roots have been pruned or damaged by larval feeding.

Table 7. Wireworms

\begin{tabular}{|c|c|}
\hline $\begin{array}{l}\text { Management } \\
\text { Options }\end{array}$ & Recommendation \\
\hline $\begin{array}{l}\text { Scouting/ } \\
\text { Thresholds }\end{array}$ & $\begin{array}{l}\text { Soil within } 8 \text { in. diameter around } \\
\text { affected plants should be excavated } \\
\text { in search of larvae in or near these } \\
\text { plants. If infestation density is in } \\
\text { question, then fields should be } \\
\text { sampled for these pests to } \\
\text { determine the best treatment } \\
\text { strategy before corn in planted. Baits } \\
\text { of oat, corn or potato buried in fields } \\
\text { and recovered in } 2 \text { to } 3 \text { weeks work } \\
\text { well to monitor wireworms. Average } \\
\text { counts greater than } 2 \text { per bait are } \\
\text { enough to recommend treatment. }\end{array}$ \\
\hline Notes & $\begin{array}{l}\text { Pesticides are available for pre-plant } \\
\text { broadcast and at-plant banded } \\
\text { applications. Soil moisture plays an } \\
\text { important role in releasing } \\
\text { insecticides from their carriers, } \\
\text { consequently wireworm control in dry } \\
\text { soils is more difficult. Pre- or post- } \\
\text { plant irrigation of dry soils and } \\
\text { adequate mixing of insecticides with } \\
\text { the soil around and in the seed } \\
\text { furrow will help to improve control. }\end{array}$ \\
\hline $\begin{array}{l}\text { Natural } \\
\text { Enemies }\end{array}$ & $\begin{array}{l}\text { Birds such as cattle egrets that } \\
\text { follow farm equipment through the } \\
\text { field eat many wireworms exposed } \\
\text { during field disking. }\end{array}$ \\
\hline
\end{tabular}

Table 7. Wireworms

\begin{tabular}{|c|c|}
\hline $\begin{array}{l}\text { Management } \\
\text { Options }\end{array}$ & Recommendation \\
\hline $\begin{array}{l}\text { Cultural } \\
\text { Controls }\end{array}$ & $\begin{array}{l}\text { Corn planted to weedy fields, or in } \\
\text { rotation from pasture or sugarcane, } \\
\text { are often exposed to very large } \\
\text { wireworm populations. Summer } \\
\text { flooding of fields is an effective } \\
\text { cultural control, providing it is } \\
\text { maintained for at least several } \\
\text { weeks. Water temperature should be } \\
\text { above } 82^{\circ} \mathrm{F} \text { for maximum control. } \\
\text { Rotation through a cycle of rice has } \\
\text { been shown to eliminate the need for } \\
\text { wireworm treatment in the } \\
\text { subsequent crop. }\end{array}$ \\
\hline
\end{tabular}

\section{Aphids}

\section{Description}

The two most commonly encountered aphids in sweet corn are the birdcherry oat aphid, Rhopalosiphum padi (L.) (Figure 17), and the corn leaf aphid, R. maidis (Fitch) (Figure 18). Both species are small to medium sized (3/32 in.), elliptical- to pear-shaped aphids. Aphids have a pair of short, tube-like structures (cornicles) that extend backward and upward from near the end of the top surface of the abdomen. Wingless adult birdcherry oat aphids are medium green with reddish areas toward the end of the abdomen and area around bases of cornicles. Wingless adult corn leaf aphids are light to medium green with short, dark green to black legs and cornicles, but lack the reddish areas around the cornicles as in birdcherry oat aphids. Nymphs of both species are similar in color and shape to adults, only smaller. Winged adult forms of both aphids have black heads and thoraxes, and green abdomens.

\section{Biology}

Adult and immature aphids feed on phloem sap sucked from leaves, stems, tassels, and husks through their long piercing-sucking mouth parts. Excess water and sugars are voided from the body. These honeydew deposits on leaves serve as a source of food for sooty mold fungi, ants, sap beetles, and flies. Winged or wingless adult females deposit live nymphs, skipping the external egg stage in Florida. Adults produce from 3 to 5 nymphs per day for up to 


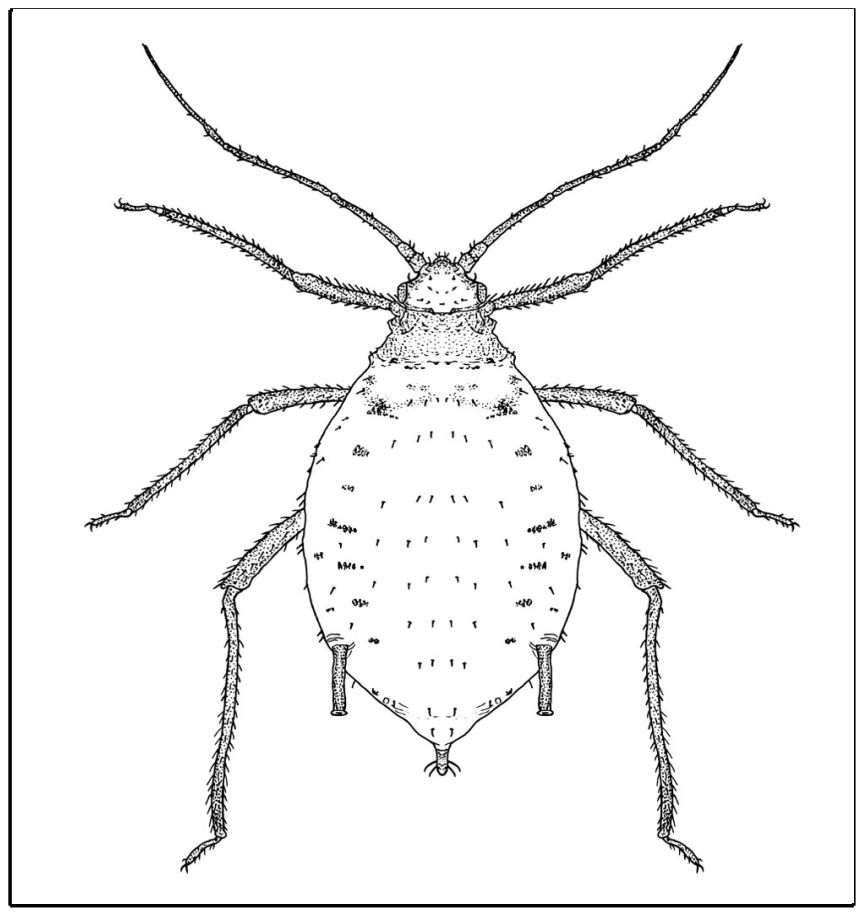

Figure 17. Birdcherry oat aphid.

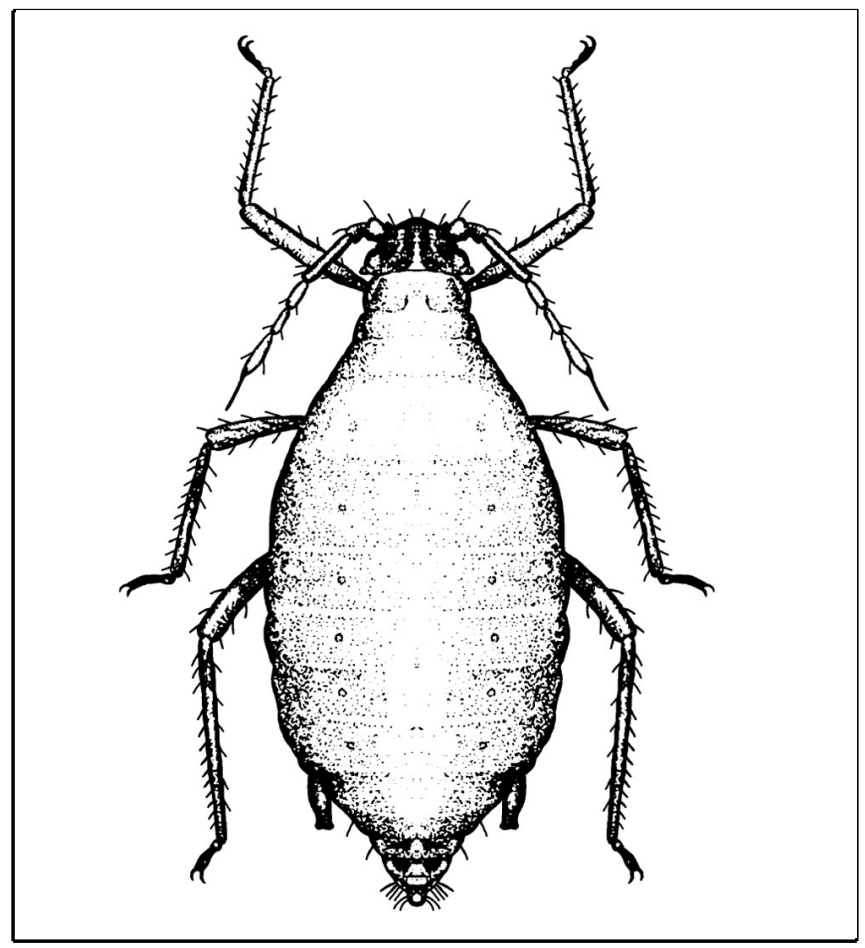

Figure 18. Corn leaf aphid.

several weeks. This allows for rapid population development. The nymphs pass through several instars before molting into adults in 7 to 10 days. There is no pupal stage in aphids.

\section{Damage}

Aphids have become a greater problem for spring sweet corn during the last several years. This may be the result of reduced pesticide inputs due to lower fall armyworm and corn earworm populations. Honeydew from aphids makes husks sticky and encourages sooty mold growth that can result in husk discoloration and grade reduction. Large populations of corn leaf aphid feeding on the emerging tassels of many plants within an area can result in poor pollen shed and fertilization. Both of these aphids can also infest sweet corn ears where their control is difficult due to feeding in concealed locations beneath dried silks, under husk wrappers and between ears and stalks.

Table 8. Aphids

\begin{tabular}{|c|c|}
\hline $\begin{array}{c}\text { Management } \\
\text { Options }\end{array}$ & Recommendation \\
\hline $\begin{array}{l}\text { Scouting/ } \\
\text { Thresholds }\end{array}$ & $\begin{array}{l}\text { Look for aphids (particularly corn } \\
\text { leaf aphids) within the corn } \\
\text { whorls, on husks beneath silk or } \\
\text { in region between ear and stalk } \\
\text { near ear base. Insecticide } \\
\text { applications for fall armyworm } \\
\text { and corn earworm control often } \\
\text { kill aphids before they can } \\
\text { develop to damaging densities. }\end{array}$ \\
\hline Notes & $\begin{array}{l}\text { Aphid populations are easier to } \\
\text { control while still infesting the } \\
\text { whorl. Aphids feeding on husks } \\
\text { are somewhat protected from } \\
\text { chemical control strategies by } \\
\text { the corn canopy and silks. } \\
\text { Pesticides are available for } \\
\text { post-emergence foliar treatments. } \\
\text { Birdcherry oat aphids are less } \\
\text { susceptible than corn leaf aphids } \\
\text { to pesticides frequently used for } \\
\text { armyworm control. Pyrethroids } \\
\text { have shown good control of } \\
\text { aphids within the whorl in } \\
\text { pre-tassel stage sweet corn. }\end{array}$ \\
\hline
\end{tabular}


Table 8. Aphids

\begin{tabular}{||l|l||}
\hline \hline \multicolumn{1}{||c||}{$\begin{array}{c}\text { Management } \\
\text { Options }\end{array}$} & \multicolumn{1}{c||}{ Recommendation } \\
\hline Enatural & $\begin{array}{l}\text { Many types of natural enemies } \\
\text { may control these aphids under } \\
\text { low pesticide input situations, } \\
\text { such as in field or sileage corn. } \\
\text { However, these aphids appear in } \\
\text { sweet corn at a time when } \\
\text { pesticide use increases for } \\
\text { armyworm, thereby greatly } \\
\text { reducing the potential impact of } \\
\text { their predators and parasitoids. }\end{array}$ \\
& $\begin{array}{l}\text { Pathogens kill many winged } \\
\text { adults before they begin } \\
\text { producing nymphs. }\end{array}$ \\
\hline \hline
\end{tabular}

Table 9. Selected insecticides approved for use on insects attacking sweet corn.

\begin{tabular}{|c|c|c|c|c|}
\hline Chemical Name & $\begin{array}{c}\text { REI } \\
\text { (hours) }\end{array}$ & $\begin{array}{l}\text { Days to } \\
\text { Harvest }\end{array}$ & Insects & Notes \\
\hline $\begin{array}{l}\text { *Ambush 2EC } \\
\text { (permethrin) }\end{array}$ & 12 & 1 & $\begin{array}{l}\text { aster leafhopper, corn earworm, } \\
\text { corn rootworm (adults), } \\
\text { cutworms, fall armyworm, } \\
\text { southern armyworm }\end{array}$ & $\begin{array}{l}\text { Do not apply more than } \\
2.0 \mathrm{lb} \text { active ingredient } \\
\text { per acre per season. }\end{array}$ \\
\hline $\begin{array}{l}\text { *Asana XL 0.66EC } \\
\text { (esfenvalerate) }\end{array}$ & 12 & 1 & $\begin{array}{l}\text { aphids, armyworms, banded } \\
\text { cucumber beetle, beet } \\
\text { armyworm (aids in control), } \\
\text { chinch bugs, corn borer, corn } \\
\text { earworm, corn rootworm, corn } \\
\text { silk fly, cutworms, flea beetles, } \\
\text { grasshoppers, sap beetles } \\
\text { (adults), stalkborers, tarnished } \\
\text { plant bug }\end{array}$ & \\
\hline $\begin{array}{l}\text { Avaunt } \\
\text { (indoxacarb) }\end{array}$ & $\begin{array}{l}12,(14 \\
\text { days for } \\
\text { hand } \\
\text { harvesting) }\end{array}$ & $\begin{array}{l}3,(35 \text { for } \\
\text { fodder \& } \\
\text { storage })\end{array}$ & $\begin{array}{l}\text { European corn borer, fall } \\
\text { armyworm }\end{array}$ & $\begin{array}{l}\text { Whorl application only. } \\
\text { No more than } 4 \\
\text { applications per season. }\end{array}$ \\
\hline $\begin{array}{l}\text { *Baythroid } 2 \\
\text { (cyfluthrin) }\end{array}$ & 12 & 0 & $\begin{array}{l}\text { chinch bugs, common stalk } \\
\text { borers, corn earworm, corn } \\
\text { rootworm adult, cutworms, fall } \\
\text { armyworm (1st and } 2 \text { nd instars } \\
\text { only), grasshoppers, silk fly, true } \\
\text { armyworm }\end{array}$ & $\begin{array}{l}\text { Maximum number of } \\
\text { applications: } 10 .\end{array}$ \\
\hline $\begin{array}{l}\text { Bt } \\
\text { (Bacillus thuringiensis) }\end{array}$ & 4 (most) & 0 & $\begin{array}{l}\text { armyworms, beet armyworm, } \\
\text { corn borers, fall armyworm, } \\
\text { loopers, southern armyworm }\end{array}$ & \\
\hline
\end{tabular}


Table 9. Selected insecticides approved for use on insects attacking sweet corn.

\begin{tabular}{|c|c|c|c|c|}
\hline Chemical Name & $\begin{array}{c}\text { REI } \\
\text { (hours) }\end{array}$ & $\begin{array}{l}\text { Days to } \\
\text { Harvest }\end{array}$ & Insects & Notes \\
\hline $\begin{array}{l}\text { *Capture } 2 \text { EC } \\
\text { (bifenthrin) }\end{array}$ & 12 & $\begin{array}{l}1 \text { - foliar } \\
30 \text { - soil } \\
\text { application }\end{array}$ & $\begin{array}{l}\text { aphids, armyworms, aster } \\
\text { leafhopper, chinch bugs, } \\
\text { common cornstalk borer, corn } \\
\text { earworm, corn rootworm adult, } \\
\text { corn silk fly, cutworms, } \\
\text { cucumber beetle adult, grubs(1), } \\
\text { mites, sap beetles, seed corn } \\
\text { beetle(1), seed corn maggot(1), } \\
\text { tarnished plant bug, webworms, } \\
\text { wireworms(1) }\end{array}$ & $\begin{array}{l}\text { Prohibited in FL coastal } \\
\text { counties. } \\
\text { (1) Soil application. Do } \\
\text { not apply more than } \\
12.8 \text { ounces of product } \\
\text { per acre per season. }\end{array}$ \\
\hline $\begin{array}{l}{ }^{*} \text { Counter } 20 \text { CR; } \\
\text { Lock 'n Load } 15 \text { G } \\
\text { (terbufos) }\end{array}$ & 48 & 60 & $\begin{array}{l}\text { billbugs, chinch bugs(1), corn } \\
\text { rootworm, cutworms } \\
\text { (suppression), flea beetles, } \\
\text { lesser corn stalk borer } \\
\text { (suppression), maize billbug, } \\
\text { seedcorn beetle, seedcorn } \\
\text { maggot, symphylans, thrips, } \\
\text { white grubs, wireworms }\end{array}$ & $\begin{array}{l}\text { (1) Early season control } \\
\text { of light to moderate } \\
\text { infestations. }\end{array}$ \\
\hline \multirow[t]{2}{*}{$\begin{array}{l}\text { *Diazinon 4E, *50W } \\
\text { (diazinon) }\end{array}$} & 24 & $\begin{array}{l}7 \\
\text { or } \\
\text { preplant }\end{array}$ & $\begin{array}{l}\text { corn earworm, corn leaf aphid, } \\
\text { corn rootworm adult, cutworms, } \\
\text { flea beetles, grasshoppers, sap } \\
\text { beetles, seed corn maggot, } \\
\text { spider mites, wireworms }\end{array}$ & \multirow{2}{*}{$\begin{array}{l}\text { Apply just before } \\
\text { planting for seed corn } \\
\text { maggot, cutworms, and } \\
\text { wireworms. Do not } \\
\text { make more than } 5 \\
\text { applications per season } \\
\text { (4E). }\end{array}$} \\
\hline & 24 & preplant only & $\begin{array}{l}\text { cutworms, seed corn maggot, } \\
\text { wireworms }\end{array}$ & \\
\hline $\begin{array}{l}\text { Extinguish } \\
\text { ((S)-methoprene) }\end{array}$ & 4 & 0 & fire ants & $\begin{array}{l}\text { Slow-acting IGR (insect } \\
\text { growth reculator). Best } \\
\text { applied early spring and } \\
\text { fall where crop will be } \\
\text { grown. Colonies will be } \\
\text { reduced after three } \\
\text { weeks and eliminated } \\
\text { after } 8 \text { to } 10 \text { weeks. } \\
\text { This is the only fire ant } \\
\text { bait that is labeled for } \\
\text { use on cropland. May } \\
\text { be applied by ground } \\
\text { equipment or aerially. }\end{array}$ \\
\hline $\begin{array}{l}\text { *Force 3G } \\
\text { (tefluthrin) }\end{array}$ & 0 & $\begin{array}{l}\text { at planting or } \\
\text { cultivation } \\
\text { within } 30 \text { days } \\
\text { of seeding } \\
\text { emergence }\end{array}$ & $\begin{array}{l}\text { billbugs, chinch bugs, corn } \\
\text { rootworm, cornstalk borers, } \\
\text { cutworms, lesser cornstalk } \\
\text { borer, red imported fire ant, } \\
\text { seedcorn beetle, seedcorn } \\
\text { maggot, white grubs, wireworms }\end{array}$ & $\begin{array}{l}\text { Only one application per } \\
\text { crop. Granules must be } \\
\text { incorporated. }\end{array}$ \\
\hline $\begin{array}{l}\text { *Furadan } \mathbf{4 F} \\
\text { (carbofuran) }\end{array}$ & $\begin{array}{l}48, \text { soil } \\
\text { foliar app., } \\
14 \text { days }\end{array}$ & $\begin{array}{l}\text { at planting, } 7 \\
\text { foliar } \\
\text { (machine } \\
\text { harvesting } \\
\text { only) }\end{array}$ & $\begin{array}{l}\text { corn rootworms, flea beetles, } \\
\text { seedcorn maggot, wireworms }\end{array}$ & $\begin{array}{l}\text { See restrictions for very } \\
\text { sandy soil. No more } \\
\text { than } 2 \text { foliage } \\
\text { applications, one if } \\
\text { applied to soil also. }\end{array}$ \\
\hline
\end{tabular}


Table 9. Selected insecticides approved for use on insects attacking sweet corn.

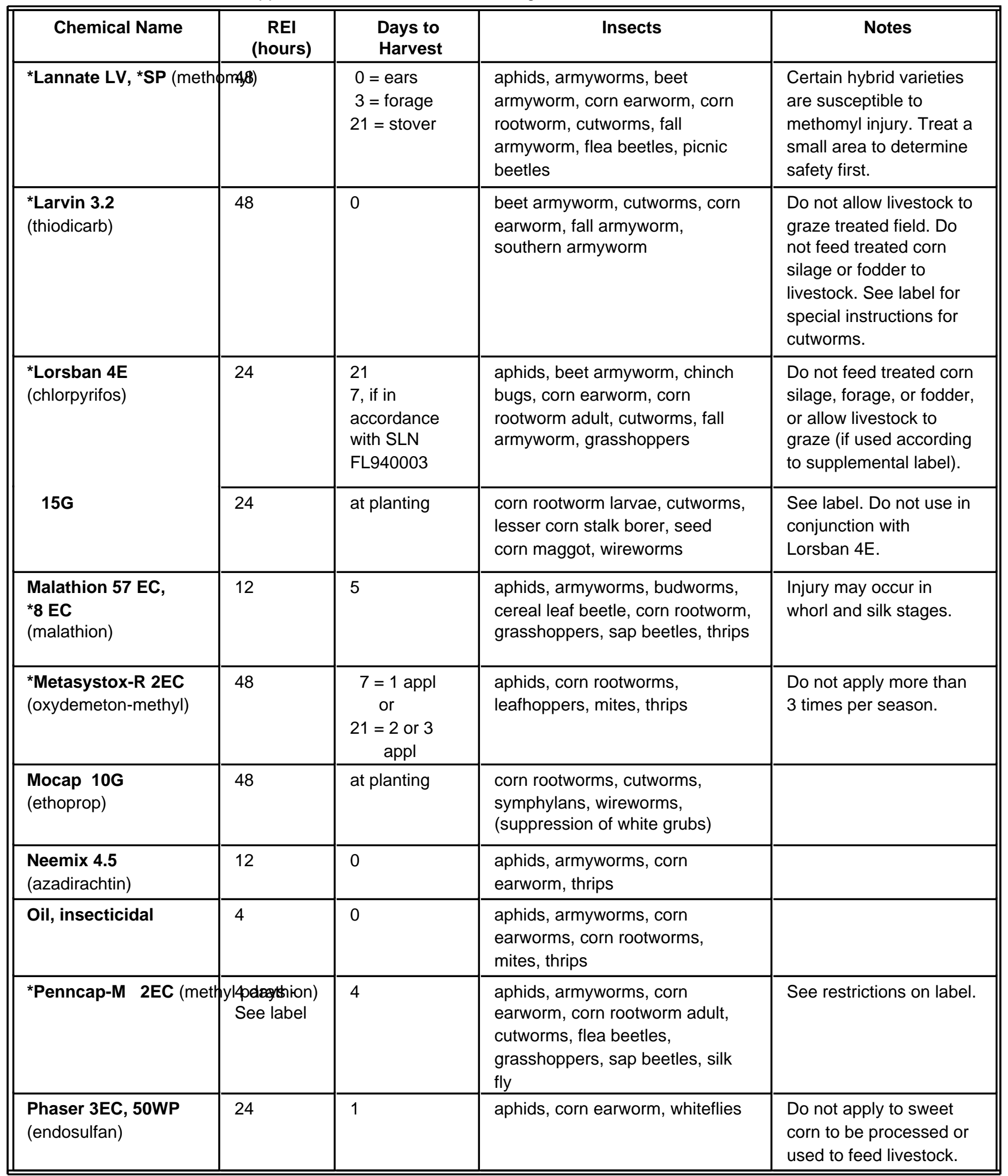


Table 9. Selected insecticides approved for use on insects attacking sweet corn.

\begin{tabular}{|c|c|c|c|c|}
\hline Chemical Name & $\begin{array}{c}\text { REI } \\
\text { (hours) }\end{array}$ & $\begin{array}{l}\text { Days to } \\
\text { Harvest }\end{array}$ & Insects & Notes \\
\hline \multirow{3}{*}{$\begin{array}{l}\text { *Pounce } 1.5 \mathrm{G} \\
\text { (permethrin) }\end{array}$} & \multirow[t]{3}{*}{12} & at planting & armyworms, cutworms & \\
\hline & & pre-emergence & $\begin{array}{l}\text { armyworms, cutworms, stalk } \\
\text { borers }\end{array}$ & \\
\hline & & foliar - 1 & $\begin{array}{l}\text { armyworms, corn borers, } \\
\text { cutworms, stalk borers }\end{array}$ & \\
\hline $\begin{array}{l}\text { Pyrellin EC } \\
\text { (pyrethrin + rotenone) }\end{array}$ & 12 & 12 hours & $\begin{array}{l}\text { aphids, flea beetles, leafhoppers, } \\
\text { loopers, mites, thrips }\end{array}$ & \\
\hline $\begin{array}{l}\text { Sevin 80S; 4F; XLR } \\
\text { (carbaryl) }\end{array}$ & 12 & $\begin{array}{l}2 \text { - Ears } \\
14 \text { - Forage } \\
48 \text { - Fodder }\end{array}$ & $\begin{array}{l}\text { armyworms, chinchbugs, corn } \\
\text { earworms, corn rootworm adult, } \\
\text { cutworms, fall armyworm, flea } \\
\text { beetles, leafhoppers, sap beetles }\end{array}$ & Highly toxic to bees. \\
\hline $\begin{array}{l}\text { Sevin } 5 \text { Bait } \\
\text { (carbaryl) }\end{array}$ & 12 & $\begin{array}{l}2 \text { - Ears } \\
14 \text { - Forage } \\
48 \text { - Fodder }\end{array}$ & $\begin{array}{l}\text { ants, crickets, cutworms, } \\
\text { grasshoppers, mole crickets, } \\
\text { sowbugs }\end{array}$ & \\
\hline Soap, insecticidal & 12 & 0 & $\begin{array}{l}\text { aphids, armyworms, leafhoppers, } \\
\text { mites, thrips }\end{array}$ & \\
\hline $\begin{array}{l}\text { SpinTor 2 SC } \\
\text { (spinosad) }\end{array}$ & 4 & 1 & armyworms, corn earworm & \\
\hline $\begin{array}{l}\text { Spod-X LC } \\
\text { (insect virus) }\end{array}$ & 4 & 0 & beet armyworm & $\begin{array}{l}\text { Treat when larvae are } \\
\text { young. }\end{array}$ \\
\hline${ }^{*}$ Telone C-35 (dichloropr & $\begin{array}{l}\text { pherdays - } \\
\text { See label }\end{array}$ & preplant & symphylans, wireworms & $\begin{array}{l}\text { See supplemental label } \\
\text { for use restrictions in } \\
\text { south and central } \\
\text { Florida. }\end{array}$ \\
\hline $\begin{array}{l}{ }^{*} \text { Thimet 20G } \\
\text { (phorate) }\end{array}$ & 48 & $\begin{array}{l}\text { at planting, } \\
\text { see label }\end{array}$ & $\begin{array}{l}\text { corn rootworms, flea beetles, } \\
\text { mites, seedcorn beetle, seed } \\
\text { corn maggot, white grubs, } \\
\text { wireworms }\end{array}$ & \\
\hline${ }^{*}$ Warrior (lambda-cyhal & theif) & $\begin{array}{l}1 \\
21 \text { for feeding } \\
\text { livestock }\end{array}$ & $\begin{array}{l}\text { aphids, aster leafhopper, beet } \\
\text { armyworm, chinch bugs, corn } \\
\text { earworm, corn rootworm, } \\
\text { cutworms, fall armyworm, flea } \\
\text { beetles, grasshoppers, mites } \\
\text { (see label for more details), red } \\
\text { imported fire ant(1), southern } \\
\text { armyworm, tarnished plant bug, } \\
\text { wireworms(1) }\end{array}$ & (1) Suppression only. \\
\hline \multicolumn{5}{|c|}{$\begin{array}{l}\text { The pesticide information presented in this table was current with federal and state regulations at the time of } \\
\text { revision. The user is responsible for determining the intended use is consistent with the label of the product } \\
\text { being used. Use pesticides safely. Read and follow label instructions. }\end{array}$} \\
\hline
\end{tabular}

